\title{
Conflict of individual freedom and community health safety: legal conditions on mandatory vaccinations and changes in the judicial approach in the case of avoidance
}

\author{
MATEUSZ PAPLICKI I, A, B, D-F, ROBERT SUSŁO 2, A, D-F , NIDAL NAJJAR R, B, D, E, \\ ORCID ID: 0000-0002-4169-9298 $\quad$ ORCID ID: 0000-0002-2680-7617 ORCID ID: 0000-0003-1239-9373 \\ PIOTR CIESIELSKI 4, B, D, E, JACEK AUGUSTYN ${ }^{5, D}$, JAROSŁAW DROBNIK², A, D \\ ORCID ID: 0000-0003-2301-5507 ORCID ID: 0000-0001-5472-1485
}

\author{
${ }^{1}$ Developmental Age Traumatology and Emergency Medicine Unit, Faculty of Medicine, Wroclaw Medical \\ University, Poland \\ ${ }^{2}$ Gerontology Unit, Public Health Department, Faculty of Health Sciences, Wroclaw Medical University, Poland \\ ${ }^{3}$ NMED Medical Centre Zlotoryja, Poland \\ ${ }^{4}$ Fire and Rescue Unit No 3, Municipal Headquarters of the State Fire Service in Wroclaw, Poland \\ ${ }^{5}$ University Clinical Hospital in Wroclaw, Poland
}

A - Study Design, B - Data Collection, C - Statistical Analysis, D - Data Interpretation, E - Manuscript Preparation, F - Literature Search, G - Funds Collection

\begin{abstract}
Summary Background. In Poland, the number of parents or caregivers, mainly declaring concern about the occurrence of vaccine injuries, refusing to subject people under the age of 19 to mandatory vaccinations has increased from 3,437 in 2010 to 30,089 in 2017. Material and methods. Legal regulations concerning vaccinations and legal literature in Poland, as well as judicial decisions concerning cases of evasion of mandatory vaccinations were reviewed.

Results. The Constitution of the Republic of Poland obliges public authorities to fight epidemic diseases. In judicial decisions, a connection between preventive vaccinations and safety and public health protection is taken for granted - mass vaccinations allow for protection of all people, who would be exposed to infectious diseases without them. Statutory obligation to submit to mandatory vaccinations exists in the law and is directly enforceable; only in the case of refusal, the State Poviat Sanitary Inspectorate (PPIS), as creditor of the obligation, may demand its implementation and indicate an effective enforcement measure; however, it is the voivode who is authorized to conduct enforcement proceedings regarding the non-pecuniary obligation. The imposed fine is a measure leading to fulfilment of the obligation of vaccination, not a penalty for its non-performance.

Conclusions. A statutory obligation to submit to protective vaccinations does not constitute a violation of constitutionally guaranteed human freedoms. As a person authorized by a specific law in the form of the Act on Preventing and Combating Infections and Infectious Diseases in Humans, this obligation overcomes the individual's freedom to exercise the right to refuse to undergo health benefits resulting from general regulations, such as the Act on Patients' Rights and Patients' Rights Ombudsman. Although the PPIS is the creditor of the statutory obligatory vaccinations, the voivode is the correct enforcement body.

Key words: vaccination, jurisprudence, public health.
\end{abstract}

Paplicki M, Susło R, Najjar N, Ciesielski P, Drobnik J. Conflict of individual freedom and community health safety: legal conditions on mandatory vaccinations and changes in the judicial approach in the case of avoidance.Fam Med Prim Care Rev 2018; 20(4): 389-395, doi: https://doi.org/10.5114/fmpcr.2018.80081.

\section{Background}

Vaccinations against infectious diseases are among the main tasks of primary care supporting public health activities [1]. This was also reflected in the Treaty on the Functioning of the European Union [2], which in art. 168 states that a high level of human health protection is ensured when defining and executing all European Union (EU) policies and activities. EU actions complementing, coordinating and supporting national policies, are aimed at improving public health, preventing disease and human ailments and removing sources of threats to physical and mental health. They include, in particular, the fight against epidemics, by "supporting research on their causes, their spreading and prevention, as well as health information and education, and monitoring of serious cross-border threats to health, early warning of such threats and combating them".

In order to implement the foregoing actions, the European Centre for Disease Prevention and Control (ECDC) was established in 2004. Its task is to support activities oriented at preventing and reducing infectious diseases, including the exchange of good practices and experience in the field of implementing vaccination programs between EU countries [4]. Among EU countries, there are significant differences in the organization of health services for the implementation of vaccination, actions undertaken by entities performing public health tasks, as well as legal regulations regarding vaccination and the degree of computerization of systems used in their implementation [5]. The ECDC cooperates closely in the field of preventive vaccination with the World Health Organization (WHO), which in 2015-2020, established goals in Europe in the form of: maintaining a polio-free status; eliminating measles and rubella; limiting hepatitis $B$ virus infections (Hepatitis B); achieving local goals for the implementation of vaccination at all administrative levels throughout the region; making factual decisions regarding the introduction of new vaccinations; and achieving financial sustainability of national vaccination programs [6]. Currently, the implementation of the above objectives is endangered, especially in the field of eliminating measles and rubella and implementing scheduled preventive vaccinations [7]. 
Research conducted among patients of primary care units shows that up to $20 \%$ of Polish parents are opposed to maintaining the obligation of preventive vaccinations, basing their opinion mainly on information obtained from the Internet and friends [8], while the percentage of people complying with recommendations on mandatory vaccinations, who perceive their logic and positive results, increases with age [9]. Typically, the knowledge of Polish parents on the justifiability of vaccinations is insufficient, as well as on the so-called cocoon vaccinations, which are particularly useful for the health of an individual and which are aimed at protecting people susceptible to disease, who cannot be vaccinated due to the existence of contraindications, by vaccinating people from their closest environment [10]. This also applies to parents of children who are at risk of developing an infectious disease associated with a specific health risk, e.g. those living with diabetes [11] or premature birth [12] In view of the very good implementation of the vaccination program in the general population [13], it should be assumed that one of the important reasons for suboptimal implementation of the vaccination program for children with chronic diseases [14], who often require an individually adapted, more complicated and thus more burdensome schedule of vaccine administration, is lack of adequate motivation of parents resulting from deficiencies in knowledge about specific health benefits of vaccinating this group of children. Vaccinations are recommended much more frequently in children under the age of 2 compared to older age groups [15], although vaccination, including against influenza, is known to induce the expected immune response even in elderly patients and should be performed to protect this sensitive subpopulation from the infectious disease itself, as well as from its complications [16]. However, even Polish primary care physicians, although aware of the benefits of influenza vaccination, who often recommend them to their patients, rarely submit to them themselves [17]. A separate problem is the fact that both recommended and mandatory vaccinations are often incorrectly documented in Poland [18]. Among the recognized factors to improve the success of infectious disease prevention among children is the education of parents regarding the desirability of vaccinations, the availability of vaccine preparations at an affordable price [19] and reimbursement of costs of mandatory vaccines in the form of highly associated preparations, reducing the number of visits necessary to carry out the required vaccination coverage and associated discomfort [20]. These activities have been carried out in Poland in recent years with varying degrees of success.

Starting from 2011, the number of refusals to undergo mandatory vaccination in people under the age of 19 increased dynamically in Poland; in 2010, there were 3,437 refusals, in 2011 $-4,689$, in $2012-5,340$, in $2013-7,248$, in $2014-12,681$, in $2015-16,689$, in $2016-23,147$, and in $2017-30,089$ refusals [21]. The indicator of the number of people evading mandatory vaccination in Poland for 1,000 people aged 0-19 increased from 0.7 in 2012 to 3.2 in 2016; by 2012, among provinces of Poland, it was the highest for the Slaskie and Pomorskie voivodships (1.36 and 1.31, respectively), while in 2016 - in the Pomorskie, Slaskie and Wielkopolskie voivodships $(6.5,4.8$ and 4.6, respectively) [22].

This situation is an increasingly important threat both for unvaccinated children and other members of society, especially older people who have not been vaccinated before or have not acquired permanent immunity as a result of the infection. It is assumed that population resistance, or herd immunity - i.e. interruption of the transmission of the infectious agent in the population due to the isolation of persons sensitive to infection from the source of infection by a sufficient number of immunized persons - is best ensured when vaccinating about $95 \%$ of the population, though accurate indicators vary for different pathogens and in case of some of them vaccination thresholds even as low as $80 \%$ may prove to be still safe enough. In Poland, in the case of diseases subject to mandatory vaccination, this percentage is still sufficient to prevent outbreaks of infectious diseases covered by mandatory vaccinations. However, while the current unfavourable tendencies to resist vaccination will not change, in the near future, due to the growing number of unvaccinated children in Poland and people in whom a vaccination was contraindicated, there is a real possibility of the return of infectious diseases which are perceived in Poland today as historical [23].

In countries where the phenomenon of refusing to vaccinate children occurred earlier or is more severe than in Poland, an increased number of cases of infectious diseases, such as measles and whooping cough, have already been observed. According to the WHO, in 2017, there were more than 4.7 thousand cases of measles in Romania. In Poland, their number in recent years has also increased significantly from 13 in 2010 to 133 in 2016. The foregoing is even more disturbing in the context of the situation in neighbouring countries, particularly in Ukraine, where due to the inefficiency of state institutions, provoked by conflicts and difficult economic situation, immunization among children in recent years has decreased by half [24]. In Poland, the main reason for the increase in the number of unvaccinated children is the concern raised by vaccine injuries declared by parents or caregivers [23]. This is reflected in the increasing number of cases brought before Provincial Administrative Courts regarding complaints against the decision of the State Sanitary Inspectorate. Meanwhile, in the case of vaccines used in Poland, vaccine injuries (Pol. Niepożqdane Odczyny Poszczepienne - NOP) occur on average with a frequency not exceeding $1 / 10,000$ vaccinations [25], hence the risk should be considered incomparably smaller, both for individual children and for society as a whole, than the resulting possible withdrawal from mandatory vaccinations of children. From detailed data for Poland, as well as by voivodships, and which is made available to reports published annually by the National Institute of Public Health - National Institute of Hygiene [26], it appears that NOP, especially serious or severe cases, concern only a small part of vaccinated people. In practice, however, courts are more willing to make use of data concerning local populations (of provinces or counties - in Poland: voivodeships and poviats, respectively), which are more specific and more closely related to the subject matter, e.g. according to data provided for evidentiary proceedings by the State Poviat Sanitary Inspectorate (Pol. Państwowy Powiatowy Inspektor Sanitarny - PPIS) in the city of Gdansk, inhabited by 464,300 people, in 2017 only 88 NOP cases were reported, most often after BCG vaccine against tuberculosis ( 35 cases). Among the vaccinated children, there was 1 case of severe NOP, in the form of convulsions and hypotonic-hyporesponsive episode, and 11 cases of serious NOP (extreme swelling, cyanosis, apnea, fever convulsions); while other reported cases of NOP were mild, not lifethreatening and generally resolved quickly (fever, pain, local reaction in the form of swelling and inflammation or enlargement of the lymph nodes). The incidence of NOP required hospitalization only in 4 children, and no registered case of NOP brought permanent adverse health consequences. An additional, retrospective review of NOP reports from all the years in which registration was required showed that there was no single NOP case with a fatal outcome in this Poviat Sanitary and Epidemiological Station $[27,28]$.

Despite the fact that cases of serious NOP are rare, in recent years in Poland, there are more and more supported initiatives of concerned parents aimed at abolishing the obligation of preventive vaccinations. A vital example of such an initiative is a bill amending the Act on Preventing and Combating Infections and Infectious Diseases in Humans [29], submitted by the Citizens' Committee of the Legislative Initiative of the National Association of Knowledge about Vaccination "STOP NOP" [30], postulating the abolition of vaccination duties in Poland and introduction of voluntary vaccination in its place. As 121,000 signatures of citizens supporting the project were collected, it was submitted to the Sejm on $28 / 03 / 2018$, and on 3/10/2018 a debate 
took place on this project, which resulted in a vote of 252 for and 158 against, with 2 abstaining from voting, for further work in Sejm committees [31], which nevertheless gave their negative opinion - after which, on 9/11/2018, the draft was rejected by the Sejm by a majority of 354 votes with 10 votes against and 16 abstentions [32]. It should be emphasized that the adoption of the postulated regulation would most likely result in a significant further reduction in the percentage of people vaccinated against infectious diseases in Poland.

\section{Material and methods}

Legal regulations effective in Poland concerning vaccinations and legal literature, as well as judicial decisions concerning cases of evading the obligation to vaccinate, were reviewed in order to analyse them as a special case illustrating the conflict between individual freedom and community health safety.

\section{Results}

\section{Health and health safety}

Knowledge about the benefits of preventive vaccination and the occurrence of NOP can be a starting point for reflection on whether health is only an individual good or also a public good, and then whether the fact of NOP occurrence should limit state actions in the area of public health protection.

According to the Constitution of the World Health Organization (WHO) [33], health depends on the cooperation of an individual and the state, and the health of all citizens is the basis of peace and security. The concept of health is defined there as a state of complete physical, mental and social well-being - health is therefore a positive notion and not just a synonym for the absence of disease or disability. Due to the fact that health affects quality of life [34], it should be regarded as a living resource rather than a life goal. The use of the highest attainable level of health is now perceived as one of the fundamental rights of human beings, regardless of economic and social conditions, which is confirmed by numerous acts of international and national law. In modern terms, and in accordance with the spirit of the Constitution of the World Health Organization, both individuals and nations have the right to health. Both individuals and entire communities must be able to meet their health needs, and it is the responsibility of the state to create appropriate conditions for them. This is beneficial to public health as medical specialty, which has been developing dynamically for a century, defined as "science and art of preventing diseases, prolonging life and promoting physical health through organized public efforts supported by actions aimed at environmental hygiene, combating infectious diseases, teaching individual hygiene principles, organizing medical and nursing services focused on early diagnosis and prophylactically targeting treatment, and development of social mechanisms that will provide every individual in society with a level of living allowing to maintain their health" [35]. On the other hand, "public health protection" should be interpreted broadly, also as an obligation of public authorities to provide such a legal and social context that allows both the removal of external threats to the individual's health, including the effective prevention and combating of infectious diseases, as well as limiting the willingness of individuals to voluntary exposure or the degradation of one's own health [36].

Recognizing health as a notion of special importance should be considered as a derivative of the acceptance of human life as a superior value. In Western civilizations, the need to protect health and life is now an inseparable part of the existing paradigm, hence, as a universal value, it remains beyond discussion [37]. As a consequence, protection of human health and life, at least in the sense of ensuring the biological existence of man, is inscribed in the very essence of the modern state; it becomes its duty, resting, in particular, on entities performing public admin- istration functions [38]. Provisions included in the Act on Preventing and Combating Infections and Infectious Diseases in $\mathrm{Hu}$ mans [29] regulate the principles and mode of identifying and monitoring the epidemiological situation, as well as taking anti-epidemic and preventive actions to neutralize sources of infection, cross infection and infectious diseases and immunization of persons susceptible to infection. These regulations should be interpreted as executing the instruction of art. 38 of the Constitution of the Republic of Poland [39] on the legal protection of the life of every human being [40].

In the most typical situation, a patient expects to receive health services. In this case, ensuring state health security involves, among others, stopping the healthcare provider from refusing to provide the patient with necessary health services to protect their life and health. The consequence of imposing the actual coercion of providing these benefits should be the state's recognition of the obligation to finance at least the necessary health services. At the same time, patients demonstrating the will to receive benefits should however be aware that they cannot expect the state to provide them with all the health services they desire. In addition to financing, the health security of citizens also depends to a large extent on full availability and efficiency of healthcare service providers, including in the area of public health. This is why any introduction of restrictions on the availability of medical services, including the introduction of limits on necessary services, is in fact a threat for the health security of citizens. Unfortunately, the state's desire to ensure full access to medical services is connected with the phenomenon of the unlimited increase of patients' health needs and, eventually, with their overuse [41]. However, the above phenomenon is not universal, as exemplified by preventive vaccinations, which do not belong to the benefits abused by patients in Poland, as they are more and more commonly avoided to the detriment of the epidemiological safety of the country. In the context of a typical patient-health system relation and its financing (based on an unlimited scale of claims and limited possibilities to meet them), it is somewhat unnatural when citizens refuse to submit to health benefits reducing health and life risks, both for themselves and other citizens; benefits that are not only free and of guaranteed availability, but which are sanctioned by the state. Nevertheless, in practice, this is the case with mandatory preventive vaccinations, which in fact leads to a threat to the health security of citizens. This provokes reflection on whether, and if so, possibly under what conditions, in the event of a contradiction between individual and public interests, the former would prevail over the other.

For a long time, the notion of interest, including public interest, has played a significant role in law and legal sciences [42]. It has a relative character, which does not however mean arbitrariness [43], but rather dependence on the social and political context [44]. Public interest can therefore be understood as a compromise between issues relevant to the existence of the state and the sphere of private interests [45] as the "interest of all people living within a politically organized community where certain legitimate interests are ensured, organized in a specific form with respect for freedom of the individual as an inalienable component of the common good" [46]. Optimally, public interest is a tool for shaping the individual's situation in a way that favours the pursuit of its individual interest [47]. However, in its essence, public interest as a normative category is opposed to individual interest, because the "public" element means following the general good rather than the individual good [48]. Balancing of these values must, in each individual case, be based on the principles of proportionality and subsidiarity [49]. Proper distinction between public interest and the "interest of the state" or the "interest of administration" as abstract beings is particularly important. These interests cannot be automatically treated as identical to the public interest, because "only the value or state of affairs can be considered a public interest, which is tantamount to benefits of individuals and which bring distinguishable good" [50]. 
Contemporary recognized medical authorities and extensive literature leave no doubt that mandatory protective vaccinations are carried out not only in the individual interest of citizens, but also, and even above all, in the interest of the general public. In this context, the obligation to undergo protective vaccination finds strong support in the provisions of the Constitution of the Republic of Poland [39], and above all art. $31 \mathrm{sec}$. 3 , which stipulates that restrictions on the use of constitutional freedoms and rights may be established only in law and only if they are necessary in a democratic state for its security or public order, or for the protection of the environment, health and public morals, or freedoms and rights of others. It should be emphasized that not every "public interest" justifies the restriction of individual freedom, but only the one that is considered "valid" constitutionally. The concept of "important public interest" is inextricably linked to the internal hierarchy of constitutional values - the value justifying the restriction must be more valuable than the limited value [51]. As a consequence, in the jurisprudence of courts, the connection between preventive vaccination and safety and public health protection is taken for granted, as mass vaccinations allow protection of all people who would be exposed to infectious diseases without them [52].

\section{Obligations of the state}

Art. $68 \mathrm{sec} .4$ of the Constitution of the Republic of Poland [39] stipulates that public authorities are obliged to combat epidemic diseases and prevent negative consequences for the health of environmental degradation. This obligation is implemented, among others, by obligatory vaccinations. In art. 27 sec. 1 point 7 of the Act on Health Care Services Financed from Public Funds [53], their performance was included in the category of services for the preservation of health, disease prevention and early detection of diseases. The subject of protective vaccinations of persons residing in the territory of the Republic of Poland is an obligation resulting directly from art. $5 \mathrm{sec} .1$ point 1 lit. b and sec. 2 and art. $17 \mathrm{sec} .1$ of the Act on Preventing and Combating Infections and Infectious Diseases in Humans [29], as well as from executive ordinances to this Act. In particular, the Regulation on Mandatory Preventive Vaccinations [54] specifies infectious diseases against which mandatory vaccination is carried out, as well as the age and groups of people subject to vaccination. According to the jurisprudence of administrative courts, such method of regulation is sufficient to assume that the obligation to undergo preventive vaccination results directly from legal provisions. The assessment does not change the fact that the Chief Sanitary Inspectorate, in the form of a communication referred to in art. $17 \mathrm{sec} .11$ of the Act on Preventing and Combating Infections and Infectious Diseases in Humans [29], published in the official journal of the Minister of Health, publishes specialized medical information relating to the technical issues of the vaccination obligation, as no additional standards can be derived from this announcement other than those resulting from laws and regulations referred to earlier $[52,55]$.

A statement of the Chief Sanitary Inspectorate has an additional legal authorization, as mandatory vaccinations are carried out by authorized persons who are conducting mandatory preventive vaccinations on dates and in accordance with detailed indications regarding the use of individual vaccines in accordance with current medical knowledge. In particular, the deadlines for the obligation to perform specific vaccinations are determined by recommendations defined in the Protective Vaccine Program effective in a given year, together with a detailed schedule of the use of individual vaccines, according to sec. 5 of the Regulation of the Minister of Health on Mandatory Preventive Vaccinations [54]. Vaccination programs for particular years precisely indicate against which infectious diseases and at what age the person should be vaccinated; for this purpose, all vaccine preparations with different degrees of association can be used, and the vaccination schedule should follow the manufac- turer's instructions. Based on the delegation included in art. 17 sec. 10 of the Act on Preventing and Combating Infections and Infectious Diseases in Humans [29], the Minister of Health specified in his Ordinance on Mandatory Preventive Vaccinations [54] that the obligation of preventive vaccination includes infectious diseases, such as diphtheria, tetanus, whooping cough, invasive Haemophilus influenzae type B infection, acute common childhood paralysis (poliomyelitis), measles, mumps and rubella. As the preservation of the designated intervals between the administration of individual doses in the vaccination schedule is important to create immunity and ensure protection of the patient and the close environment, unwarranted discontinuation of vaccination can also cause measurable negative effects in the form of increased susceptibility to disease. As a consequence, in the case of refusal of mandatory preventive vaccinations, the enforcement order includes the obligation to carry out vaccinations that have not been carried out so far, despite having to be vaccinated during the period indicated in the vaccination calendar [56].

Issuing orders and decisions or applying to other authorities for their issue, in cases specified in the provisions on combating infectious diseases, should be made in accordance with art. 5 point 4 of the Act on the State Sanitary Inspectorate [57] to the scope of its operation in the field of preventing and combating infectious diseases. However, the Act on Preventing and Combating Infections and Infectious Diseases in Humans [29], imposing a legally effective, hence directly enforceable obligation to undergo mandatory vaccinations, does not introduce any grounds for issuing decisions by the State Sanitary Inspectorate [58]. Therefore, in the absence of a proprietary resolution of the PPIS, in the form of an administrative decision that would subject a minor child to preventive vaccination, there is also no basis for recognizing that the PPIS was a competent authority to conduct the above-mentioned non-cash obligation within the meaning of art. $20 \mathrm{sec} .1$ of the Act on Enforcement Proceedings in Administration [59], while, pursuant to art. $20 \mathrm{sec} .1$ point 1 of this Act, it is the voivode [60] that voivode [60] that - as the official appointed by the central government to administer the given province of Poland - is the authority with general jurisdiction to conduct enforcement proceedings in respect of nonpecuniary obligations. However, in the event of non-compliance with mandatory preventive vaccinations, the PPIS is entitled, as the creditor of the obligation, to demand its implementation [61], as well as, pursuant to art. 28 of the Act, to indicate to the governor of a province, being the enforcement body, an enforcement measure which, according to the PPIS, will effectively lead to the performance of the enforced obligation by the obligor. Consequently, a fine imposed on the person obliged to perform the protective vaccination of the child does not constitute a penalty for failure to perform this duty; it is supposed to lead to the performance of this obligation by threatening to make the victim suffer financial distress [62]. Establishment and final confirmation in judicial decisions of the above division of roles between individual authorities (PPIS - as the authority requesting the enforcement of the statutory vaccination obligation and indicating the enforcement measure, usually in the form of a fine, and the voivode - as the authority authorized to enforce the non-pecuniary obligation, which is the obligation to vaccinate) required time, but its consequent consistent application proved to be crucial to ensure the effectiveness of the proceedings.

\section{Obligation of parents}

Pursuant to art. $93 \mathrm{sec} .1$ of the Family and Guardianship Code [63], parental responsibility is vested in both parents. Art. $95 \mathrm{sec} .1$ of this Act stipulates that this authority includes, in particular, the obligation and the right of parents to perform custody over the person and property of a child and to raise a child respecting his dignity and rights. Pursuant to art. $95 \mathrm{sec}$. 
3 of the Act, parental authority should be exercised as required by the well-being of a child and social interest. Art. 98 sec. 1 of the Act stipulates that parents are statutory representatives of a child remaining under their parental authority, and if the child remains under parental authority of both parents, then each of them may act independently as a statutory representative. In light of the foregoing legal regulations, parents who are entitled to parental responsibility are responsible for fulfilling the obligation of providing preventive vaccination to their child [58]. Since each parent can act independently as a child's statutory representative, this executive title in administrative enforcement proceedings aimed at enforcing the obligation for preventive vaccination of a child may, though not necessarily, be issued against each of the parents individually [60]. It is not always justified to enforce the obligation to subject the child to vaccinations from both parents, because it is possible that only one of the spouses is opposed to having the child subject to vaccination. Consequently, the mere fact of indicating only one of the parents, without taking into account the circumstances of the case, cannot determine the defect of the enforcement order [64].

It should be emphasized that the obligation to undergo mandatory protective vaccinations also means the obligation to undergo medical qualification tests in order to exclude contraindications to mandatory vaccinations based on art. $17 \mathrm{sec}$. 2 of the Act on Preventing and Combating Infections and Infectious Diseases in Humans [29]. The necessity to perform such a test within 24 hours before vaccination, resulting from art. $17 \mathrm{sec} .3$ of this Act, results in the fact that refusal to participate in such tests makes it impossible to carry out vaccination, and is therefore in fact a refusal to submit to mandatory preventive vaccination [52]. Therefore, it should be emphasized that undergoing mandatory preventive vaccination cannot be effectively counteracted on the basis of art. 16 of the Act on Patients' Rights and Patients' Rights Ombudsman [65], which is a general regulation regarding the patient's right to consent to the provision of certain health services or lack of such consent, after obtaining relevant information [52]. The Act on Preventing and Combating Infections and Infectious Diseases in Humans [29], as a specific provision requiring mandatory preventive vaccinations, therefore takes precedence over the general right to refuse to undergo medical treatment based on art. 16 of the Act on Patients' Rights and Patients' Rights Ombudsman, which is confirmed by the previous judicial approach [66]. There is also no legal basis to exclude the obligation to subject the child to mandatory vaccinations only because of the parents' concerns in this respect, in the absence of any evidence of the foregoing concerns [67].

\section{Obligation of physicians}

As mentioned earlier, enforcement of the requirement of preventive vaccination by law is secured by an administrative constraint. According to art. $17 \mathrm{sec} .9$ of the Act on Preventing and Combating Infections and Infectious Diseases in Humans [29], the responsibility of the physician exercising preventive health care is to notify about the obligation to undergo vaccinations, as well as to inform about recommended vaccinations a person obliged to undergo mandatory vaccinations or a person in legal guardianship over a minor or helpless person or her actual guardian - whom, pursuant to art. $3 \mathrm{sec} .1$ point 1 of the Act on Patients' Rights and Patients' Rights Ombudsman [65], is a person who, without statutory duty, has permanent care over a patient who, due to age, health or mental state of care, requires it. It should also be mentioned that in accordance with art. $17 \mathrm{sec} .7$ of the Act on Preventing and Combating Infections and Infectious Diseases in Humans [29], the birth of a live child imposes on the person issuing a certificate of living birth the obligation to establish an immunization card and a vaccination book for the child.

Children with medical contraindications for vaccination, in particular an increased risk of vaccine injuries, are exempt from appropriate mandatory vaccinations, or the performance of a given vaccination may be postponed by the physician until such contraindications cease to exist. In the case of any doubts, the primary care physician qualifies the children for specialist consultations. Based on art. $8 \mathrm{sec} .1$ of the Regulation on Mandatory Preventive Vaccinations [54], the physician conducting specialist consultation of a person in which a medical qualification test provides grounds for a long-term postponement of mandatory vaccination records the result of specialist consultations in medical documentation, including a contraindication period, the type of contraindicated vaccines or an individual vaccination program with an indication of the types of vaccines used and the date of the next specialist consultation.

\section{Conclusions}

The statutory obligation to undergo protective vaccinations does not constitute a violation of constitutionally guaranteed human freedoms, because these freedoms are not absolute and must take into account the rights of others, including the right to live in a society free from infectious diseases which are prevented by vaccination [52].

The statutory obligation of preventive vaccination means inadmissibility of the patient's right to refuse to undergo medical treatment with reference to art. 16 of the Act on Patients' Rights and Patients' Rights Ombudsman [65]. This provision, of a general nature, is applicable only if provisions of separate specific laws do not provide otherwise - and in the case of mandatory preventive vaccination, this separate detailed regulation is the Act on Preventing and Combating Infections and Infectious Diseases in Humans [29]. This Act imposes an obligation to submit to protective vaccinations and does not provide for the right of the patient, or his parent or guardian, to refuse consent for protective vaccination, just the opposite; it establishes a general obligation to undergo protective vaccinations [52]. As a consequence, the Act on Preventing and Combating Infections and Infectious Diseases in Humans has priority when considering the possibility of refusing vaccinations as it is a detailed regulation (Lat. lex specialis) in relation to a general regulation (Lat. lex generalis) in the form of the Act on Patients' Rights and Patients' Rights Ombudsman [68, 69].

Due to the fact that, according to respective jurisdiction, the statutory obligation of preventive vaccination overcomes the individual's freedom to exercise the right to refuse to undergo a health service, the state usually acts in a particularly balanced way by its authorities. It should be emphasized that public administration bodies - the PPIS and the voivode - have already developed a correct and effective way to enforce the obligation to vaccinate. In previous years, parents refusing to submit their children to vaccinations effectively appealed to administrative courts [70]; however, the current procedure - in which the PPIS is a creditor and the voivode is an enforcement authority-does not provide legal grounds for parents to effectively avoid compliance with the statutory obligation to vaccinate. 


\section{References}

1. Tyszko $P$, Nitsch-Osuch A, Mińko $M$, et al. Primary health care tasks in implementing the main operations of public health. Fam Med Prim Care Rev 2016; 18(3): 394-397, doi: https://doi.org/10.5114/fmpcr/62876.

2. Traktat o Funkcjonowaniu Unii Europejskiej - wersja skonsolidowana [cited 15.10.2018]. Available from URL: https://eur-lex.europa. eu/legal-content/PL/TXT/PDF/?uri=CELEX:12012E/TXT\&qid=1542064644018 (in Polish).

3. Council of the European Union. Council conclusions on vaccinations as an effective tool in public health. 6.12.2014 (D.U.UE 2014/C 438/04) [cited 15.10.2018]. Available from URL: http://www.consilium.europa.eu/uedocs/cms_data/docs/pressdata/en/lsa/145973. pdf.

4. Council conclusions on childhood immunisation: successes and challenges of European childhood immunisation and the way forward. 8.7.2011 (D.U.UE 2011/C 202/02) [cited 15.10.2018]. Available from URL: https://eur-lex.europa.eu/legal-content/PL/TXT/ PDF/?uri=CELEX:52011XG0708(02).

5. European Center for Disease Control and Prevention. Immunisation information systems in the EU and EEA [cited 15.10.2018]. Available from URL: http://ecdc.europa.eu/sites/portal/files/documents/immunisation-systems.pdf.

6. World Health Organization Regional Office for Europe. European Region Vaccine Action Plan 2015 to 2020 [cited 15.10.2018]. Available from URL: http://www.euro.who.int/_data/assets/pdf_file/0007/255679/WHO_EVAP_UK_V30_WEBx.pdf.

7. World Health Organization Regional Office for Europe. European Region Vaccine Action Plan 2015 to 2020 Midterm Report 2018 [cited 15.10.2018]. Available from URL: http://www.euro.who.int/_data/assets/pdf_file/0007/381184/evap-midterm-report-eng.pdf.

8. Łopata E, Biesiada P, Kałucka S. Opinie rodziców na temat zasadności szczepień obowiązkowych w Polsce. Fam Med Prim Care Rev 2014; 16(3): 252-254 (in Polish).

9. Kałucka S, Łopata E. Age-conditioned differences in parents' attitudes towards compulsory vaccination. Fam Med Prim Care Rev 2016; 18(4): 425-428, doi: https://doi.org/10.5114/fmpcr.2016.63695.

10. Jaroszewska K, Gawlak M, Fijałkowska A, et al. Wiedza rodziców o strategii kokonowej szczepień przeciw grypie i krztuścowi. Fam Med Prim Care Rev 2014; 16(4): 341-344 (in Polish).

11. Nitsch-Osuch A, Kamińska I, Jaroszewska K, et al. Wiedza rodziców na temat szczepień ochronnych u dzieci z cukrzycą typu 1. Fam Med Prim Care Rev 2014; 16(3): 266-268 (in Polish).

12. Nitsch-Osuch A, Pieńkowska A, Gyrczuk E, et al. Stan wiedzy i postrzeganie szczepień ochronnych przez matki noworodków przedwcześnie urodzonych. Fam Med Prim Care Rev 2013; 15(2): 151-153 (in Polish).

13. Nitsch-Osuch A, Olszówka M, Topczewska-Cabanek, et al. Realizacja Programu Szczepień Ochronnych w wybranej poradni podstawowej opieki zdrowotnej w Warszawie u dzieci urodzonych w latach 2006-2008. Fam Med Prim Care Rev 2013; 15(2): 149-150 (in Polish).

14. Nitsch-Osuch A, Wiśniewska A, Gołębiak I, et al. Realizacja Programu Szczepień Ochronnych u dzieci z chorobami przewlekłymi w wybranej poradni podstawowej opieki zdrowotnej w Warszawie. Fam Med Prim Care Rev 2013; 15(3): 359-361 (in Polish).

15. Nitsch-Osuch A, Kozerska A, Topczewska-Cabanek A, et al. Realizacja Programu Szczepień Ochronnych u dzieci z zastosowaniem szczepionek zalecanych w wybranej poradni medycyny rodzinnej. Fam Med Prim Care Rev 2012; 14(3): 410-413 (in Polish).

16. Sławin A, Brydak L, Doniec Z, et al. Influenza vaccine efficacy in patients aged 60-75 years in the 2016/2017 season. Fam Med Prim Care Rev 2018; 20(3): 263-266, doi: https://doi.org/10.5114/fmpcr.2018.78271.

17. Gutknecht $\mathrm{P}$, Winiarski T, Trzeciak B, et al. Opinions and behavior of family doctors concerning vaccinating against influenza. Fam Med Prim Care Rev 2016; 18(3): 241-243, doi: https://doi.org/10.5114/fmpcr/63462.

18. Nitsch-Osuch A, Wyszyńska D, Topczewska-Cabanek A, et al. Analiza niezgodności w dokumentacji szczepień ochronnych u dzieci z wybranych szkół w Warszawie. Fam Med Prim Care Rev 2011; 13(3): 459-461 (in Polish).

19. Cepuch G, Zych B, Wyżga A, et al. Wybrane czynniki wpływające na wykonywanie szczepień zalecanych u dzieci. Fam Med Prim Care Rev 2014; 16(3): 211-212 (in Polish).

20. Nitsch-Osuch A, Frąc L, Jaroszewska K, et al. Realizacja Programu Szczepień Ochronnych w Interwencyjnym Ośrodku Preadopcyjnym w Otwocku w latach 2007-2011. Fam Med Prim Care Rev 2014; 16(2): 140-142 (in Polish).

21. PZH-NIZP. Gdzie można znaleźć informacje na temat liczby niezaszczepionych dzieci? [cited 15.10.2018]. Available from URL: http:// szczepienia.pzh.gov.pl/faq/gdzie-mozna-znalezc-informacje-na-temat-liczby-niezaszczepionych-dzieci/ (in Polish).

22. PZH-NIZP. Biuletyny Szczepienia Ochronne w Polsce za lata 2010-2017 [cited 15.10.2018]. Available from URL: http://wwwold.pzh.gov. pl/oldpage/epimeld/index_p.html\#05 (in Polish).

23. Dziwisz S. Prawne aspekty przeprowadzenia i egzekwowania szczepień. Obowiązek szczepień ochronnych. Państwo i Społeczeństwo 2015; 2: 143-144 (in Polish).

24. Lechowicz-Dyl K. Wzrasta liczba nieszczepionych dzieci. [cited 15.10.2018]. Available from URL: https://silesion.pl/wzrasta-liczba-nieszczepionych-dzieci-25-02-2018 (in Polish).

25. Zgliczyński W, Cianciara D. Szczepienia ochronne dzieci i młodzieży w Polsce - wybrane zagadnienia. Biuro Analiz Sejmowych BAS - Analizy 2015; 2(122): 1-10. Available from URL: http://orka.sejm.gov.pl/WydBAS.nsf/0/BECC03C19435EAFFC1257DE7004F5400/\$file/Analiza_BAS_2015_122.pdf (in Polish).

26. Czarkowski M, Kondej B, Staszewska-Jakubik E, et al. Szczepienia ochronne w Polsce w 2016 roku. Instytut Zdrowia Publicznego - Państwowy Zakład Higieny 2017 [cited 15.10.2018]. Available from URL: http://wwwold.pzh.gov.pl/oldpage/epimeld/2016/Sz_2016.pdf (in Polish).

27. Wyrok Wojewódzkiego Sądu Administracyjnego w Gdańsku z dnia 23 maja 2018 r., sygn. II SAB/Gd 29/18 (in Polish).

28. Państwowy Powiatowy Inspektor Sanitarny w Gdańsku. Stan bezpieczeństwa sanitarnego miasta Gdańska za rok 2017 [cited 15.10.2018]. Available from URL:http://www.psse.gda.pl/pliki-do-pobrania/-1/1052-raport-o-stanie-bezpieczestwa-sanitarnegomiasta-gdaska-za-2017-rok/file (in Polish).

29. Ustawa z dnia 5 grudnia 2008 r. o zapobieganiu oraz zwalczaniu zakażeń i chorób zakaźnych u ludzi (Dz.U. 2008 Nr 234 poz. 1570 , ze zm.) (in Polish).

30. Ogólnopolskie Stowarzyszenie Wiedzy o Szczepieniach STOP NOP [cited 15.10.2018]. Available from URL: http://stopnop.com.pl/ustawa/ (in Polish).

31. Projekt ustawy ruchu antyszczepionkowego trafił do komisji. TVN24 4.10.2018 r. [cited 15.10.2018]. Available from URL: https://www. tvn24.pl/wiadomosci-z-kraju,3/sejm-wyslal-do-komisji-projekt-ustawy-o-likwidacji-obowiazku-szczepien,873375.html (in Polish).

32. Sejm odrzucił projekt ustawy o dobrowolności szczepień. Polityka Zdrowotna 9.11.2018 r. [cited 10.11.2018]. Available from URL: http://www.politykazdrowotna.com/38666,sejm-odrzucil-projekt-ustawy-o-dobrowolnosci-szczepien.htm (in Polish).

33. Konstytucja Światowej Organizacji Zdrowia, Porozumienie zawarte przez Rządy reprezentowane na Międzynarodowej Konferencji Zdrowia i Protokół dotyczący Międzynarodowego Urzędu Higieny Publicznej, podpisane w Nowym Jorku dnia 22 lipca 1946 r. (Dz.U. z 1948 r. Nr 61 poz. 477) (in Polish). 
34. Dercz M. Samorzqd terytorialny w systemie ochrony zdrowia. Warszawa: Międzykomunalna Spółka Akcyjna Municipium; 2005: 12-13 (in Polish).

35. Winslow C. The untilled fields of public health. Science 1920; 51(1306): 22-33, doi: https://doi.org/10.1126/science.51.1306.23.

36. Garlicki L, Wojtyczek K. Komentarz do art. 31. In: Garlicki L, Zubik M, eds. Konstytucja Rzeczypospolitej Polskiej. Komentarz. Tom 2. Warszawa: Wydawnictwo Sejmowe; 2016: 55-100 (in Polish).

37. Rabiega A. Ochrona życia i zdrowia ludzkiego $w$ działaniach podmiotów administrujqcych w sferze opieki zdrowotnej. Warszawa: Wydawnictwo Sejmowe; 2009: 5-11 (in Polish).

38. Sarnecki P. Komentarz do art. 38. In: Garlicki L, ed. Konstytucja Rzeczypospolitej Polskiej. Komentarz. Tom 3. Warszawa: Wydawnictwo Sejmowe; 1999: 2-5 (in Polish).

39. Konstytucja Rzeczypospolitej Polskiej z dnia 2 kwietnia 1997 r. uchwalona przez Zgromadzenie Narodowe w dniu 2 kwietnia 1997 r., przyjęta przez Naród w referendum konstytucyjnym w dniu 25 maja 1997 r., podpisana przez Prezydenta Rzeczypospolitej Polskiej w dniu 16 lipca 1997 r. (Dz. U. 1997 Nr 78 poz. 483, ze zm.) (in Polish).

40. Wyrok Wojewódzkiego Sądu Administracyjnego w Warszawie z dnia 5 lipca 2018 r., sygn. VII SA/Wa 2847/17 (in Polish).

41. Leowski J. Rola i miejsce państwa w systemie ochrony zdrowia. Prawo Med 2000; 6-7(2): 23-25 (in Polish).

42. Komierzyńska E, Zdyb M. Klauzula interesu publicznego w działaniach administracji publicznej. Ann UMCS 2016; 2 (63): 161 (in Polish).

43. Borkowski A. Interes publiczny a partnerstwo publiczno-prywatne. In: Blicharz J, ed. Prawne aspekty prywatyzacji. Wrocław: Uniwersytet Wrocławski; 2012: 443-460. Available from URL: http://bibliotekacyfrowa.pl/Content/39996/00_01_Start.pdf (in Polish).

44. Blicharz J. Kategoria interesu publicznego jako przedmiot działania administracji publicznej. Acta Universitatis Wratislaviensis. Przeglad Prawa i Administracji 2004; 40: 39-43 (in Polish).

45. Wieczorek E, Komentarz do art. 6. In: Powałowski A, ed. Ustawa o swobodzie działalności gospodarczej. Komentarz. Warszawa: Wolters Kluwer; 2007: 65-70 (in Polish).

46. Wyrzykowski M. Pojęcie interesu społecznego w prawie administracyjnym. Warszawa: Wydawnictwo Uniwersytetu Warszawskiego; 1986: $28-48$ (in Polish).

47. Boć J. Prawo administracyjne. Wrocław: Wydawnictwo Kolonia Limited; 2010: 7-24 (in Polish).

48. Laskowska M. Interes publiczny. In: Bojanowski E, Żukowski K, eds. Leksykon prawa administracyjnego. 100 podstawowych pojęć. Warszawa: CH Beck; 2009: 100-104 (in Polish).

49. Żurawik A. Interes publiczny w prawie gospodarczym. Warszawa: CH Beck; 2013: 127-175 (in Polish).

50. Szydło M. Wolność działalności gospodarczej jako prawo podstawowe. Bydgoszcz: Oficyna Wydawnicza Branta; 2011: 165-188 (in Polish).

51. Garlicki L, Zubik M. Komentarz do art. 22. In: Garlicki L, Zubik M, eds. Konstytucja Rzeczypospolitej Polskiej. Komentarz. Tom 1. Warszawa: Wydawnictwo Sejmowe; 2016: 570-586 (in Polish).

52. Wyrok Naczelnego Sądu Administracyjnego w Warszawie z dnia 21 lutego 2018 r., sygn. II OSK 1089/16 (in Polish).

53. Ustawa z dnia 27 sierpnia 2004 r. o świadczeniach opieki zdrowotnej finansowanych ze środków publicznych (Dz.U. 2004 Nr 210 poz. 2135, ze zm.) (in Polish).

54. Rozporządzenie z dnia 18 sierpnia 2011 r. w sprawie obowiązkowych szczepień ochronnych (Dz. U. 2011 Nr 182 poz. 1086, ze zm.) (in Polish).

55. Wyrok Naczelnego Sądu Administracyjnego w Warszawie z dnia 12 czerwca 2014 r., sygn. II OSK 1312/13 (in Polish).

56. Wyrok Naczelnego Sądu Administracyjnego w Warszawie z dnia 7 lutego 2018 r., sygn. II OSK 934/16 (in Polish).

57. Ustawa z dnia 14 maja 1985 r. o Państwowej Inspekcji Sanitarnej (Dz.U. 1985 r. Nr 12 poz. 49, ze zm.) (in Polish).

58. Wyrok Naczelnego Sądu Administracyjnego w Warszawie z dnia 30 stycznia 2018 r., sygn. II OSK 2358/17 (in Polish).

59. Ustawa z dnia 17 czerwca 1966 r. o postępowaniu egzekucyjnym w administracji (Dz.U. 1966 Nr 24 poz. 151, ze zm.) (in Polish).

60. Wyrok Naczelnego Sądu Administracyjnego w Warszawie z dnia 25 kwietnia 2018 r., sygn. II OSK 2434/17 (in Polish).

61. Postanowienie Wojewódzkiego Sądu Administracyjnego w Poznaniu z dnia 7 lutego 2018 r., sygn. IV SA/Po 1082/17 (in Polish).

62. Wyrok Wojewódzkiego Sądu Administracyjnego w Warszawie z dnia 12 kwietnia 2018 r., sygn. VII SA/Wa 1845/1 (in Polish).

63. Ustawa z dnia 25 lutego 1964 r. Kodeks rodzinny i opiekuńczy (Dz.U. 1964 Nr 9 poz. 59, ze zm.) (in Polish).

64. Wyrok Wojewódzkiego Sądu Administracyjnego w Bydgoszczy z dnia 10 kwietnia 2018 r., sygn. II SA/Bd 102/18 (in Polish).

65. Ustawa z dnia 6 listopada 2008 r. o prawach pacjenta i Rzeczniku Praw Pacjenta (Dz.U. 2009 Nr 52 poz. 417, ze zm.) (in Polish).

66. Wyrok Wojewódzkiego Sądu Administracyjnego w Warszawie z dnia 17 kwietnia 2018 r., sygn. VII SA/Wa 2274/17 (in Polish).

67. Wyrok Naczelnego Sądu Administracyjnego w Warszawie z dnia 26 kwietnia 2018 r., sygn. II OSK 1504/16 (in Polish).

68. Wyrok Naczelnego Sądu Administracyjnego w Warszawie z dnia 17 kwietnia 2014 r., sygn. II OSK 338/13 (in Polish).

69. Wyrok Naczelnego Sądu Administracyjnego w Warszawie z dnia 4 lutego 2015 r., sygn. II OSK 1509/13 (in Polish).

70. Szczęch N. Problematyka przymusowych szczepień ochronnych u dzieci na tle orzecznictwa sądów administracyjnych. RAP 2016; 16(1): 187-211. Available from URL: https://rocznikiadministracjiiprawa.publisherspanel.com/api/files/download/556392.pdf (in Polish).

Tables: 0

Figures: 0

References: 70

Received: 03.12.2018

Reviewed: 06.12 .2018

Accepted: 11.12 .2018

Address for correspondence:

Mateusz Paplicki, PhD

Zakład Traumatologii i Medycyny Ratunkowej Wieku Rozwojowego UM

ul. Bujwida 44a

50-345 Wrocław

Polska

Tel.: +48 71 328-60-45

E-mail: mateusz.paplicki@umed.wroc.pl 